\title{
THE AETIOLOGY OF TROPICAL SPRUE AS SEEN IN HONG KONG AND ITS RELATION TO COELIAC DISEASE
}

\author{
Colonel J. F. WEBB, M.C., M.D., M.R.C.P.(Ed.), Late R.A.M.C. \\ Cambridge Military Hospital, Aldershot
}

\begin{abstract}
SUMMARY: Over a period of twenty years the writer has been concerned in the study of tropical sprue and to a lesser extent, adult coeliac disease. The aetiology of coeliac disease is known, and Professor Booth in his Oliver-Sharpey lecture has suggested a hypothesis for the pathogenesis of gluten in that disease. Evidence is here presented that the production of oxidative rancidity in unsaturated cooking fats, exposed to the heat of a tropical humid atmosphere is aetiologically significant in tropical sprue as seen in Hong Kong. It is believed that the toxic products of the rancid fat exert the same effect as gluten does in coeliac disease.
\end{abstract}

This paper discusses some possible aetiological factors in tropical sprue as seen in Hong Kong emphasising the ingestion of rancid fats as the main one. It indicates a close relationship between that disease and coeliac disease, suggesting that the main differences are:-

The specific noxious factor causing the small intestinal cell damage, and

In the case of coeliac disease, the relatively longer period of exposure to the noxious substance.

It is based on the writer's experience of tropical sprue when he served in Hong Kong from 1950 to 1954, and 1958 to 1961 (Webb 1956, and Webb and Simpson 1966). In the intervening years he has had the opportunity of studying coeliac disease both in England and Germany (Webb and Reploh 1969). Since Dicke's (1950) classical observations in Holland it has been confirmed that coeliac disease, occurring in children and adults, is produced by gluten, which is found in wheat and rye flour, causing damage to the absorbing cell of the small intestine in certain individuals. Precisely why a normal dietary constituent should affect selected persons is not understood. A process by which this damage is effected has been suggested by Booth (1970) in his Oliver-Sharpey Lecture and it is this lecture which stimulated the author to put his thoughts on the aetiology of tropical sprue to paper, and in so doing indicate the relationship stated above.

The similarity of the clinical features occurring in tropical sprue and coeliac disease which together form the majority of the causes of malabsorption is shown in Table I.

Table I

Clinical features common to both coeliac disease and tropical sprue

\begin{tabular}{|c|c|}
\hline Feature & Feature \\
\hline $\begin{array}{l}\text { Diarrhoea } \\
\text { Weight loss } \\
\text { Anorexia } \\
\text { Lassitude } \\
\text { Glossitis } \\
\text { Steatorrhea }\end{array}$ & $\begin{array}{l}\text { Malnutrition } \\
\text { Megaloblastic anaemia } \\
\text { Low serum folate/B12 levels } \\
\text { Abnormal small intestine barium studies } \\
\text { Abnormality of the small intestine mucosa in the form of villous atrophy } \\
\text { (not so severe in sprue) }\end{array}$ \\
\hline
\end{tabular}


The abnormality of the mucosa of the jejunum can be seen in biopsy specimens obtained by means of the Crosby capsule (Crosby and Kugler 1957). These specimens show in varying degree atrophy of the villi and abnormalities of the absorbing cells on the surface of the villi. These abnormalities are reversible by removal of the noxious substance from the diet, for example, gluten in the case of coeliac disease, and in the case of tropical sprue recovery can be brought about by admission of the patient to hospital and treatment with folic acid parenterally, or by mouth.

In the author's experience of treating patients with tropical sprue, the response to treatment was accelcrated when folic acid was accompanied by an antibiotic regime, but antibiotics when used alone were of no value and in some cases exacerbated the illness.

Figures 1 and 2 show a patient with tropical sprue before and after treatment and
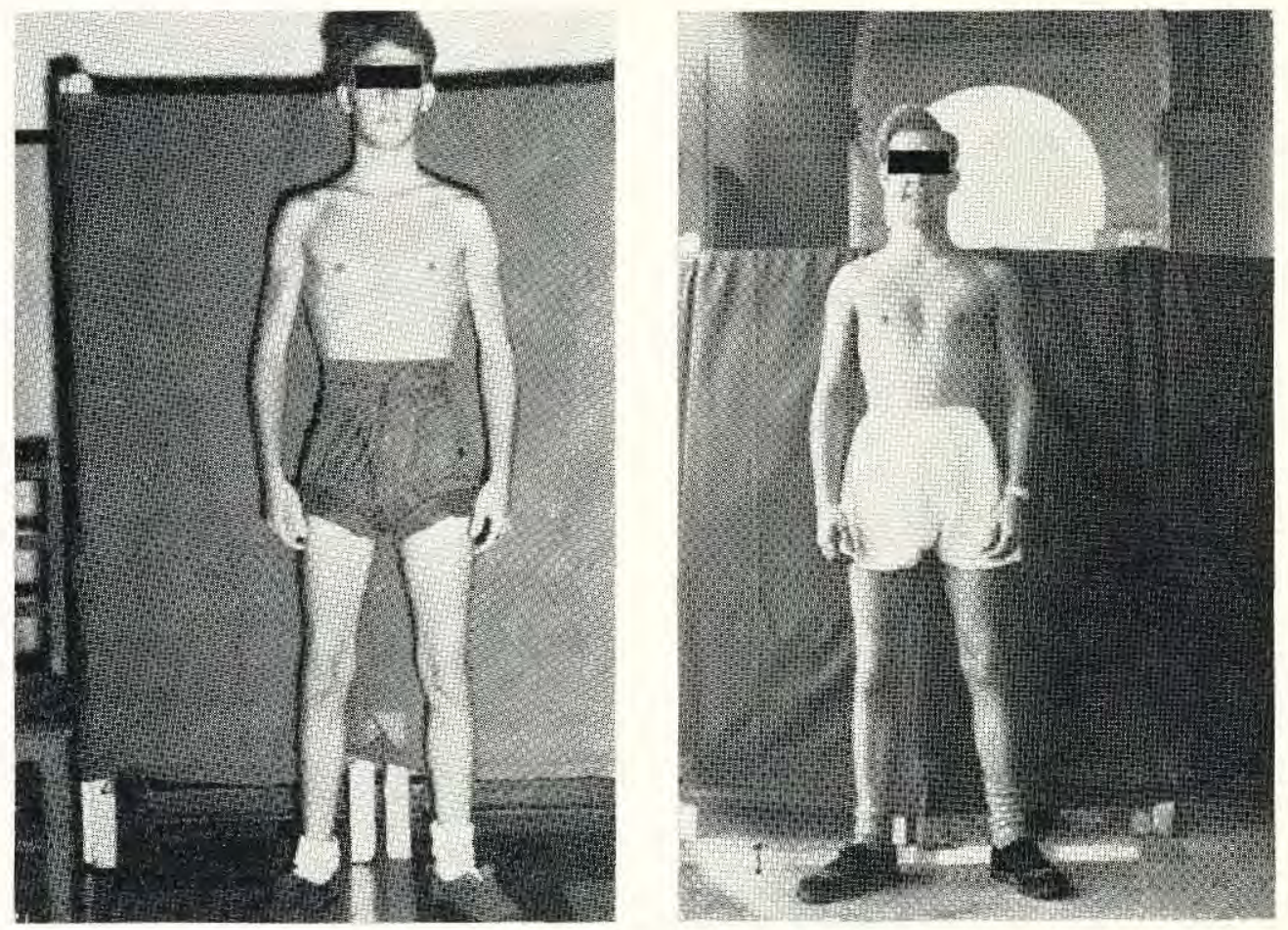

Figs. 1 and 2. A patient with tropical sprue before and after treatment,

Figures 3 and 4 show the improvement in the severe glossitis in the same patient. This patient demonstrated the classical clinical features of tropical sprue and megaloblastic anaemia. He recovered on treatment within a few weeks and was fit for normal duty. Small intestine biopsy techniques were not available at the time this patient was studied.

Figure 5 shows a patient who suffered from coeliac disease diagnosed at the age of 17. She also demonstrated clinical features similar to those of the patient described above with, in addition, marked bony deformities related to the osteodystrophy which presumably ${ }_{t a}{ }^{-}$resulted from the longer duration of her illness. 

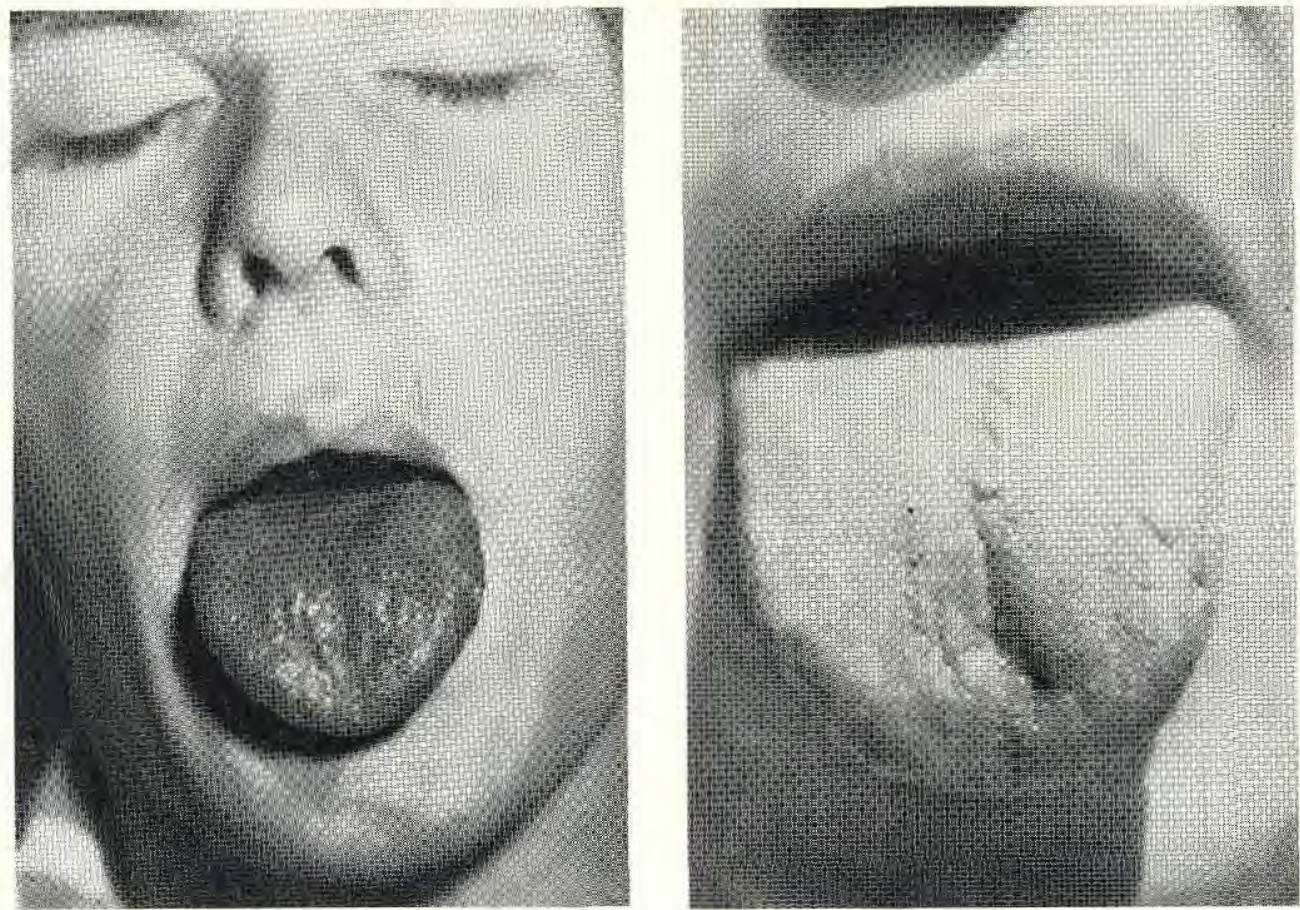

Figs, 3 and 4. Severe glossitis in patient in Fig. 1 before and after recovery.

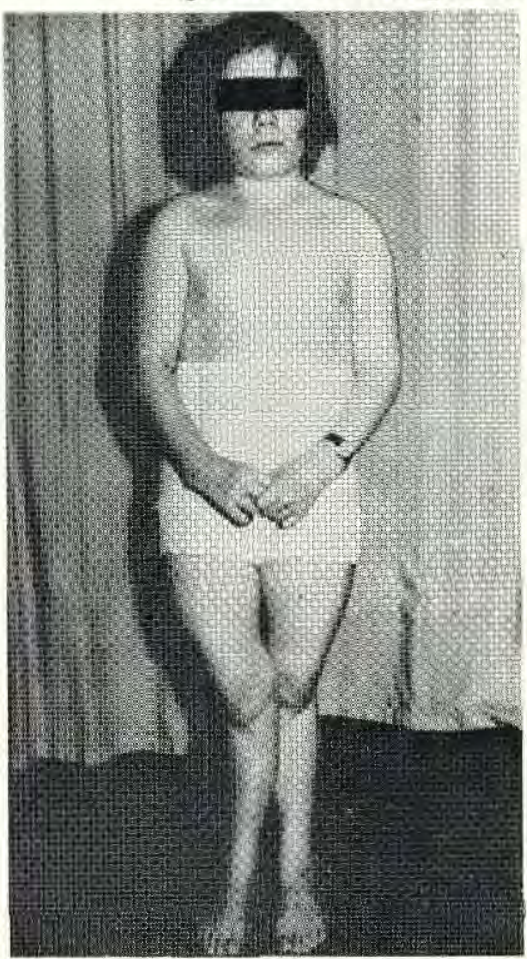

Fig. 5. A patient aged 17 years, suffering from adult coeliac disease. Note the small stature and limb deformity.

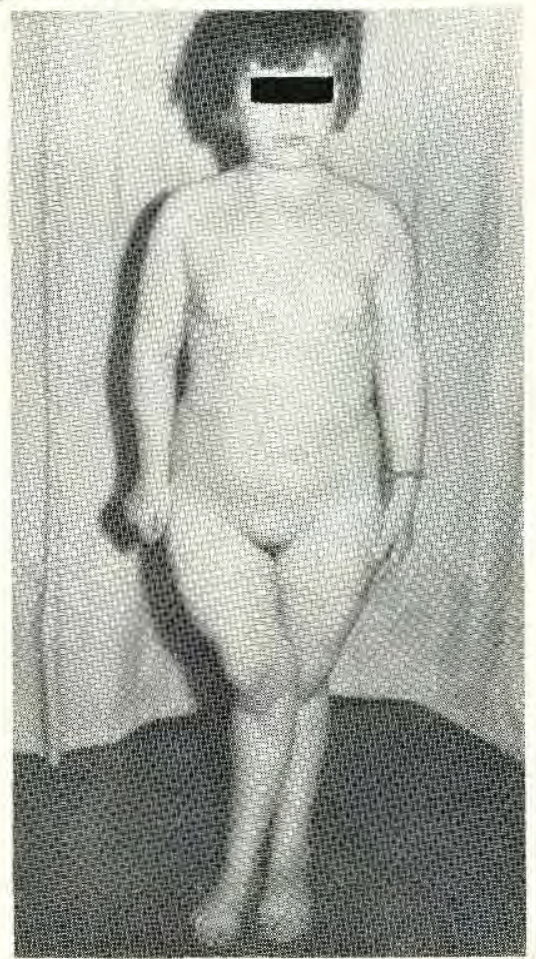

Fig. 6. The same patient one year after treatment. She had improved in height and weight and breast devclopment is clearly seen. 
Figure 6 shows the same patient after treatment with a gluten free diet and supportive therapy, which in this case extended over one year. She had increased in height, gained weight, her periods had commenced and the development of secondary sexual characteristics can be seen in the photograph.

Figures 7,8 and 9 show the microscopic appearance of biopsy specimens taken during the course of treatment over one year and demonstrate reversion of the small intestine villi from a "flat" mucosa to near normal, over the period of treatment. Figures 10 and 11 show the macroscopic appearance of the biopsy specimens at the beginning and at the end of treatment. A similar recovery of the small intestine villi has been described in patients with tropical sprue in Hong Kong (Webb and Simpson 1966) and in patients seen in Malaya and Singapore, the same pattern has been described and beautifully illustrated by England and O'Brien (1966).

As noted above the author had a unique opportunity of studying the possible aetiological factors in tropical sprue as it occurred in Hong Kong, and the similarity in the pathogensis of coeliac disease and tropical sprue is the main subject of this paper.

During 1950 to 1951 an outbreak of acute tropical sprue which assumed epidemic proportions occurred amongst British troops in Hong Kong (Rosenthal 1952 and Webb 1956) and since then the disease has been present in the endemic form described by Webb and Simpson (1966).
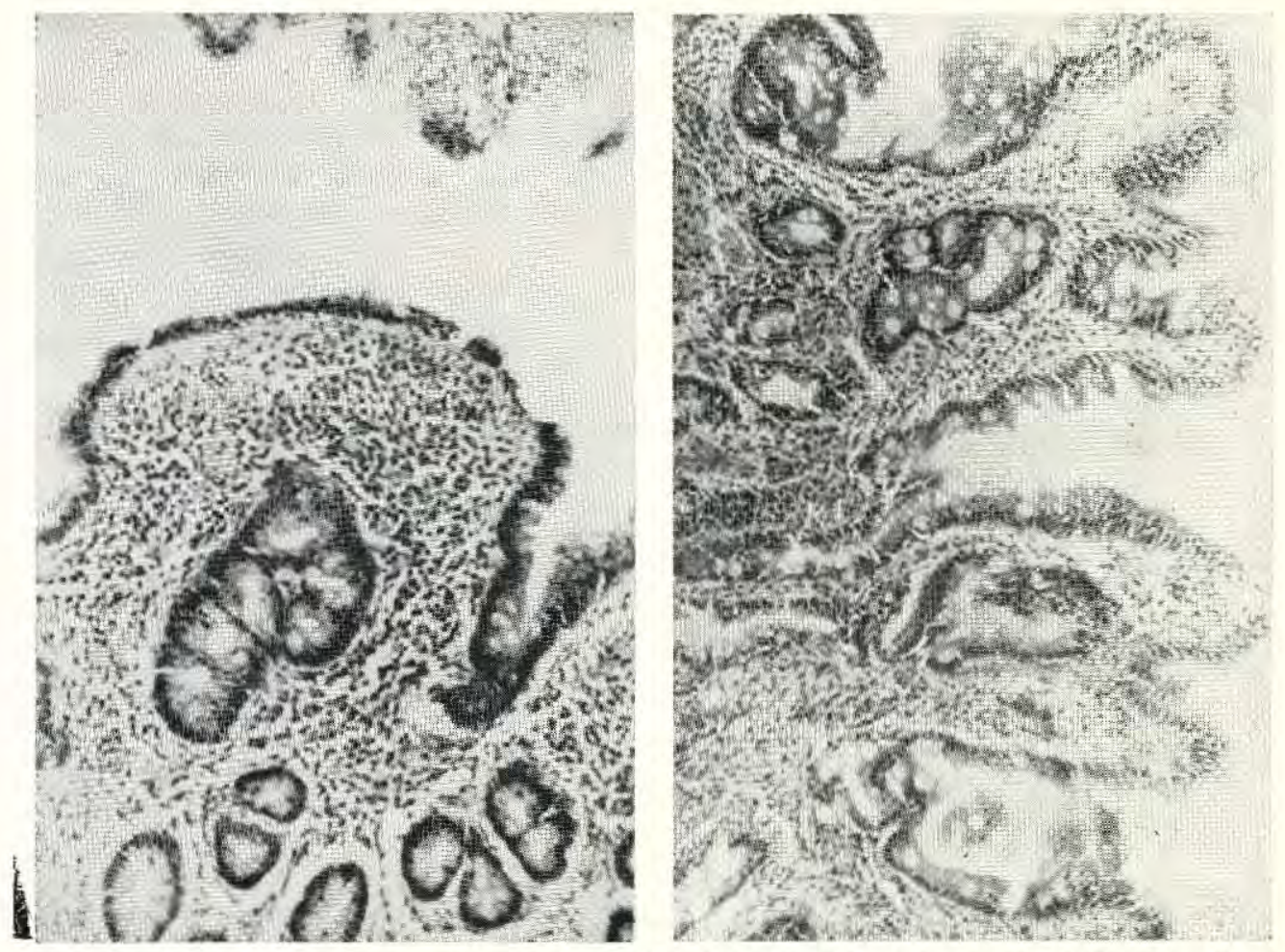

Fig, 7. The pre-treatment microscopic appearance of the jejunum of the patient in Fig. 5. The flat cells on the surface of the villi with marked cellular infiltration can be seen. Fig. 8 . The jejunal biopsy on the patient in Fig. 5 six months after treatment showing the development of the villi. 


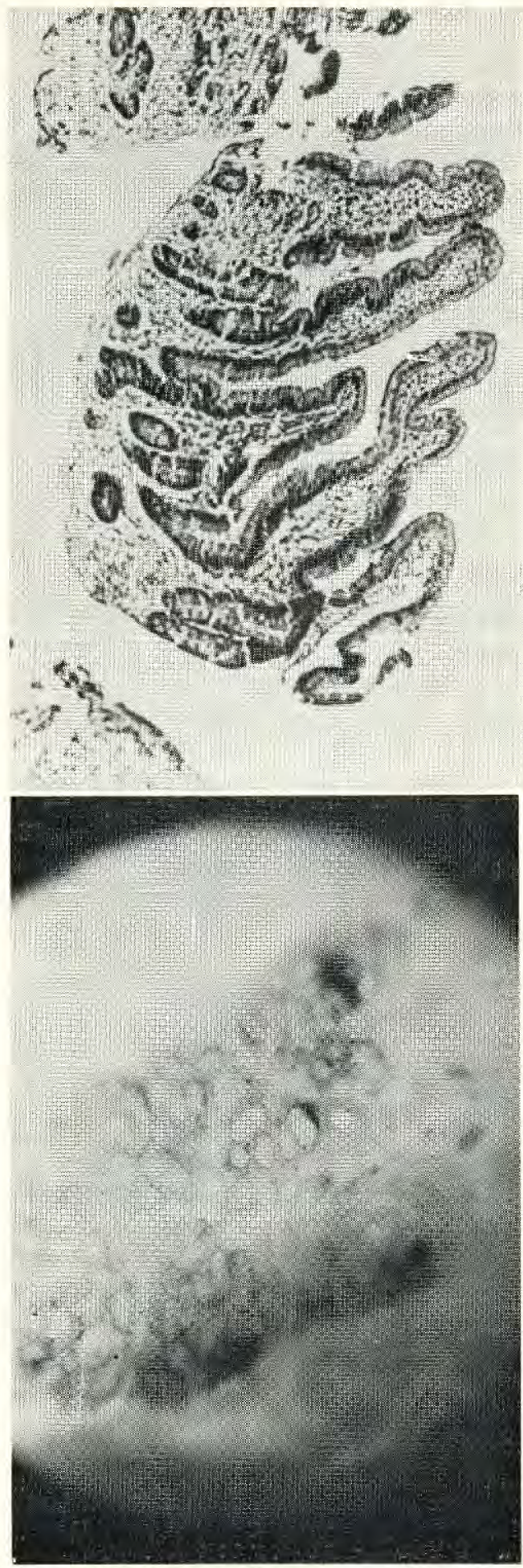

Fig. 9. The normal appearance of the villi in the jejunal biopsy of the patient in Fig. 5 one year after treatment.

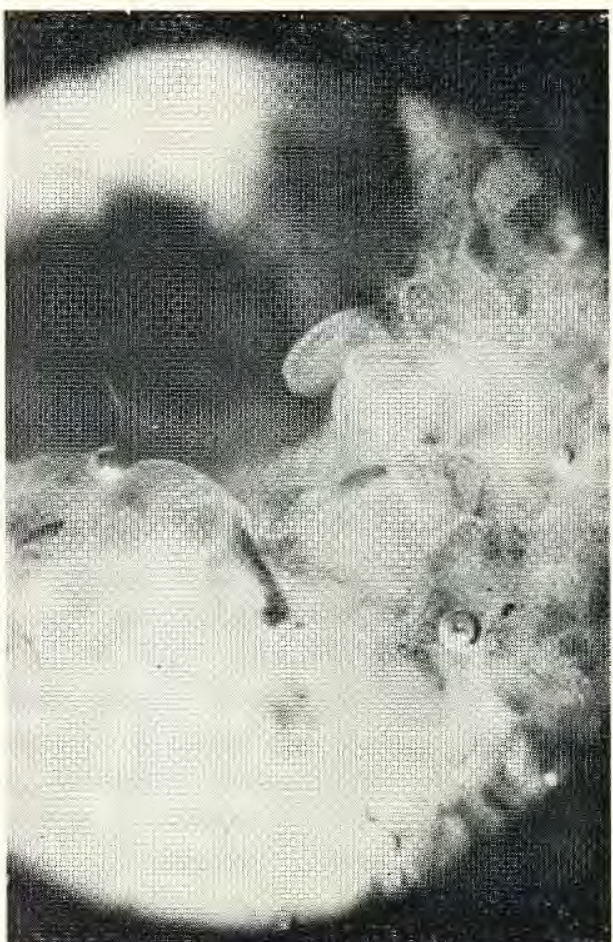

Fig. 10. The macroscopic appearance of the biopsy in Fig. 7 demonstrating the flat mucosal appearance.

Fig. 11. The macroscopic appearance one year after treatment demonstrating the growth of the villi. 
Hong Kong is a more or less enclosed community consisting of fairly clearly separated groups of people namely, Chinese residents forming the bulk of the population, European civilians, and members of the Armed Forces. The latter were the smallest group numbering about 16,000 with, in addition, a brigade of Gurkha troops, during each of the years 1951, 1952 and 1953. The Royal Air Force and Naval contingents were small compared to the Army and the majority of the patients seen were British soldiers. These soldiers rarely left the colony during their three-year tour and thus formed an excellent group for study. The civilian Chinese and European residents did not suffer from sprue, or at least it would appear so since enquiry indicated none were seen in the civilian hospitals or by civilian practitioners. Although these two latter groups experienced different conditions of living in regard to housing conditions and availability of refrigeration facilities, they represented a reasonable control group with regard to climatic conditions, environment, and exposure to infectious diseases. Long residence and acilimatisation cannot be regarded as mitigating their value in this respect since these factors were considered to be of aetiological significance in the past by such authorities as Manson (1880) and Fairley (1936). The great majority of the soldiers were fit young men, about twenty years of age, and they lived in military camps sited on the istand or in the countryside around Kowloon, or in quarters in the cities of Kowloon and Hong Kong. All took their leisure at some time of the week in either Kowloon or Hong Kong. They lived healthy lives although exposed to the hazards of infection incidental to residence amongst Chinese rice fields where human excreta was used as manure. The olservations over a year of one hundred randomly selected soldiers showed that the tendency was to gain rather than to lose weight (Table II) so their diet can be concluded to be reasonably nutritious. Only 84 completed the observation period.

Table II

The mean weight change in 84 healthy controls during one year's residence in Hong Kong, expressed as a percentage of initial weight demonstrating that the tendency was to gain weight in a tropical climate

\begin{tabular}{c|c|c|c}
\hline Weight change & Frequency & Weight change & Frequency \\
\hline-10.0 to -8.1 & 1 & 11.0 to 11.9 & 4 \\
-8.0 to -6.1 & 4 & 12.0 to 13.9 & 4 \\
-6.0 to -4.1 & 2 & 14.0 to 15.9 & 0 \\
-4.0 to -2.1 & 4 & 16.0 to 17.9 & 2 \\
-2.0 to -0.1 & 3 & 18.0 to 19.9 & 0 \\
0.0 to 1.9 & 14 & 20.0 to 21.9 & 0 \\
2.0 to 3.9 & 20 & 22.0 to 23.9 & 1 \\
4.0 to 5.9 & 9 & 24.0 to 25.9 & 0 \\
6.0 to 7.9 & 10 & 26.0 to 27.9 & 0 \\
8.0 to 9.9 & 5 & 28.0 to 29.9 & 1 \\
\hline
\end{tabular}

Number measured $=84$. Mean $=+4.16$ per cent. Standard deviation $=6.3$ per cent $t=6.2$. For 83 degrees of freedom $P=<0.001$ which is highly significant.

The patients studied had the classical features common to both tropical sprue and coeliac disease. During the years 1951, 1952 and 1953 the incidence of cases showed a marked decrease (9/1000 in $1951,7 / 1000$ in 1952 and 2/1000 in 1953) and the following comments refer to an explanation of the decreased incidence from an aetiological aspect. There were too few women and children in the community for any useful conclusion to be drawn about them and, as stated, the majority of the soldiers were young men so that age as a factor could not be assessed. Hereditary, endocrine, and emotional factors did not appear to be important. The amount of exercise taken did not influence the 
incidence of the disease which affected sedentary workers just as much as those living active regimental lives.

In Table III it may be seen that the majority of the patients, namely seventy-three,

Table III

The period of residence in the colony prior to onset of symptoms, in 107 cases of sprue

\begin{tabular}{l|c|c|c|c|c|c|c|c|c}
\hline $\begin{array}{c}\text { Residence } \\
\text { in months }\end{array}$ & $1-3$ & $4-6$ & $7-9$ & $10-12$ & $13-15$ & $16-18$ & $19-21$ & $22-24$ & 30 \\
\hline $\begin{array}{l}\text { Number of } \\
\text { cases }\end{array}$ & 24 & 19 & 15 & 15 & 8 & 7 & 4 & 13 & 2 \\
\hline
\end{tabular}

developed symptoms of their illness during the first 12 months of their residence in the colony indicating long residence in an endemic area is not a pre-requisite to the development of sprue.

\section{Infection}

No positive evidence to favour infection by either bacteria or virus as an aetological agent could be adduced. There did not appear to be a greater incidence of cases amongst soldiers living in the vicinity of the rice fields, and thus more exposed to fly-borne disease, than there was amongst those living in the urban areas. Fever was not a feature of patients seen, although in some, the illness did commence with an explosive diarrhoea and the passing of frequent fluid stools. However in a number, and especially in the type of case just mentioned, exhibition of sulpha drugs did produce an amelioration of symptoms, even to the extent of the patient pronouncing himself cured. Critical analysis of this statement indicated that the stools had become less frequent and more solid to assume the pale unformed character of the typical sprue stool. In no case did sulpha drugs or antibiotics result in a normal stool or recovery of the patient.

At least three fresh stools from each patient were examined for parasites and pathogenic bacteria with negative results, and sigmoidoscopy showed only a mild erythema of the bowel wall which disappeared after treatment.

\section{Seasonal incidence}

Hong Kong enjoys a climate characterised by a hot humid summer, extending from July to September and the remainder of the year is mild autumn, extending to near winter conditions in December, January and February. Figure 12 shows the incidence of the disease during 1951, 1952 and 1953 and although the number of cases decreased over the years, it illustrates the maximal occurrence in the summer months when the temperature and humidity were at their highest.

\section{Relation to other diseases}

Figure 13 shows the incidence of sprue related to that of dysentery and infective hepatitis, the two commonly occurring infectious diseases seen in the community and it can be seen that there is little temporal or quantitative relationship between the three diseases. Malaria was the only pest-borne disease liable to occur with any frequency, but as all troops were taking protective measures the incidence of the disease was very low and could not be related to that of sprue. 


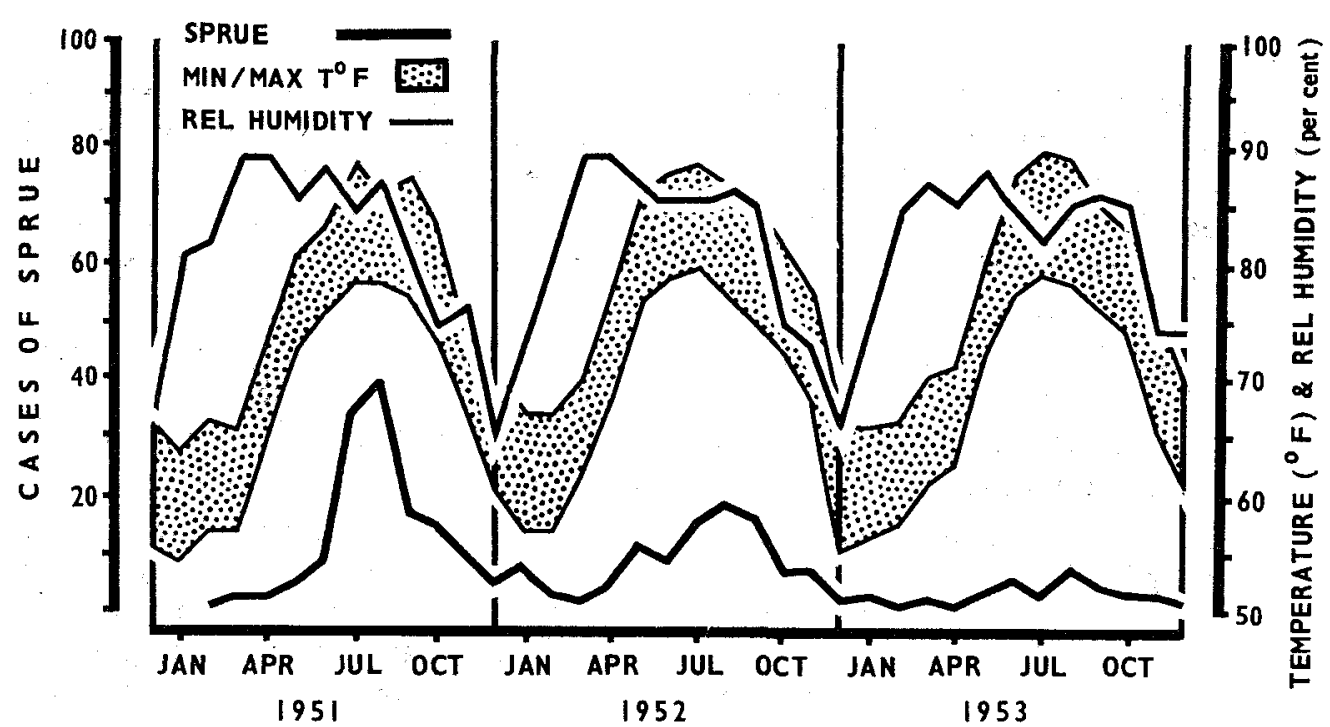

Fig. 12. The incidence of sprue related to temperature and humidity over a three year period in Hong Kong. It can be seen that although the climatic conditions were unchanged the incidence of sprue decreased.

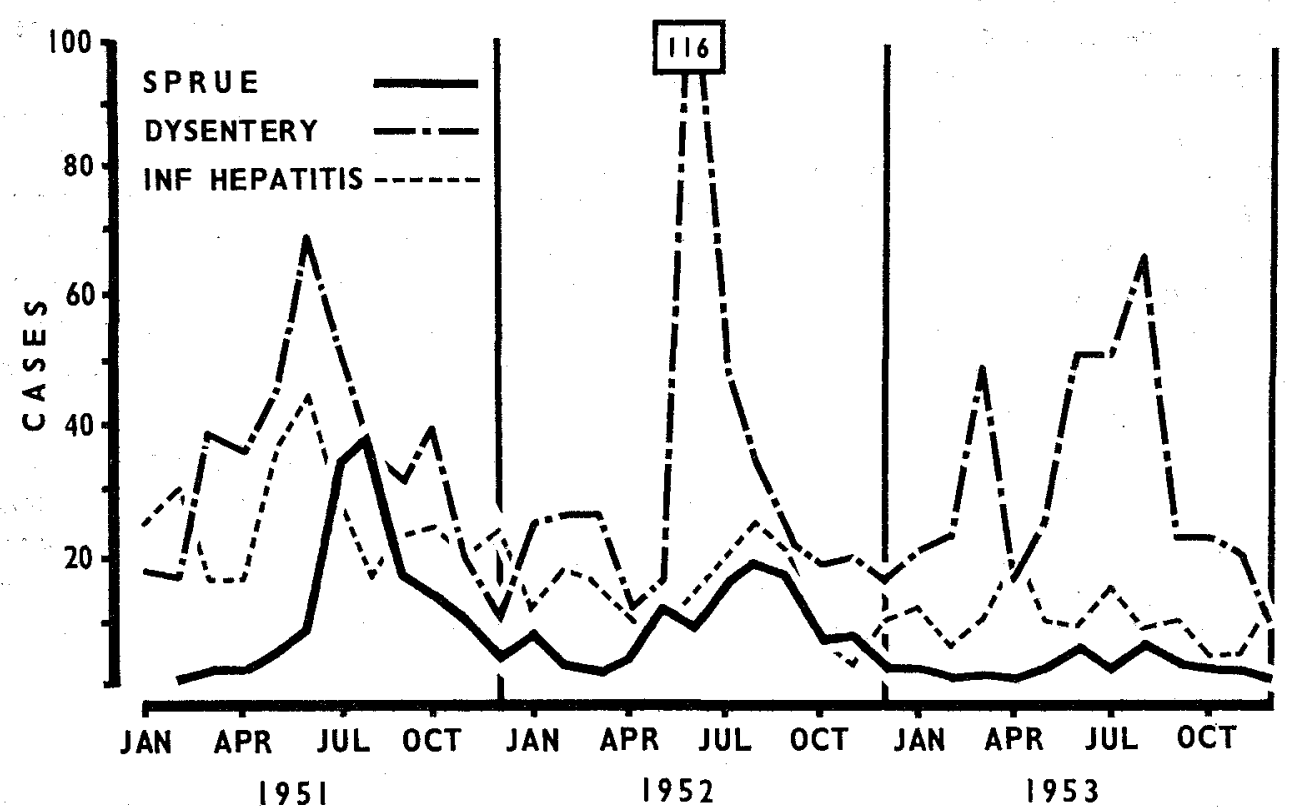

Fig. 13. A comparison of the incidence of dysentery, a bacterial disease, and infective hepatitis, a virus disease, compared with that of sprue over the three year period 1951 to 1953. There is little relationship between the incidence of the three diseases except that the highest of each occurred in the summer months.

Figures 12 and 13 by courtesy of the University of Manchester Department of Medical Illustration, The Royal Infirmary, Manchester M13 9WL. 


\section{Diet}

It was considered that the decreased incidence of the disease during the years 1951 to 1953 might result from the improved refrigeration facilities for food which had occurred during the period, and thoughts therefore turned to the possibility that a prime aetiological factor might be something taken in or with the food. That such a causal factor had been demonstrated in coeliac disease was considered as further support for this hypothesis.

Investigation of the dietary habits of the patients suffering from sprue revealed that they ate at least one and usually two fried meals per day, and these were consumed in unit cookhouses or in NAAFI or civilian establishments. It is believed that this reflected the dietary habits of most of the military personnel in Hong Kong.

As stated no cases of sprue occurred amongst the Gurkha soldiers, of which there were nearly 3,000 men in Hong Kong, and as their camp was sited in the country outside Kowloon amongst the rice fields, they were perhaps more exposed to infection than many of the other service personnel. It was found that the fat used for cooking by the Gurkhas was a substance called ghee derived from cow or goat milk and that it was usually consumed with the meal, whereas the fat used for cooking for British soldiers was usually of vegetable oil origin, and furthermore, the same fat was used for repeated frying. In the case of the Chinese residents, although their cooking fat was of vegetable origin, it was also consumed with the meal and not available for repeated frying. It was found that the supplier of fat to NAAFI and unit establishments during 1951 was very much to be criticised in the hygiene of his establishment and in the source of his meat for rendering to fat. This supplier was changed in 1952 which might be a further reason for the decreased incidence of cases in 1952 and 1953.

Vegetable fats, especially when unsaturated, may develop a high level of oxidative rancidity when heated repeatedly as in frying (Whipple 1936, and Hilditch 1947). In this condition they may give rise to deleterious effects in the alimentary tract when consumed (a positive Kreis test and a raised peroxide value are the main evidence of oxidative rancidity, and both increase together in rancid fat). About 100 samples of fat were taken from various shops, unit cookhouses and civilian restaurants and their Kreis test and peroxide value assessed. Table IV shows the Kreis test and peroxide value on some of these samples.

Table V shows a comparison of the environmental factors affecting the groups of Military, European and Chinese residents in Hong Kong, noting the Gurkha troops as a separate group. It may be seen that all groups were exposed to similar hazards with the exception of the type of cooking fat used and the liability of it to develop oxidative rancidity. British troops were exposed to the ingestion of fats of this type in units, NAAFI establishments and local restaurants.

\section{Discussion}

Although jejunal biopsy is the sheet anchor of diagnosis in coeliac disease there are no histological features of the abnormal jejunal mucosa which are pathognomonic of that disease (Rubin, Eidelman and Weinstein 1970). The similarity of the clinical picture in coeliac disease and tropical sprue has been here presented and it seems reasonable to assume that, although the abnormality of the jejunal mucosa is not so severe as that seen in coeliac disease, the difference may only be one of degree. Indeed, whilst the 
Table IV

Kreis test and peroxide value of some of the 100 samples of fat taken from various establishments

\begin{tabular}{|c|c|c|c|c|}
\hline $\begin{array}{l}\text { Sample } \\
\text { number }\end{array}$ & Description & $\begin{array}{l}\text { Used for } \\
\text { frying }\end{array}$ & $\begin{array}{l}\text { Peroxide } \\
\text { value }\end{array}$ & Kreis test \\
\hline $\begin{array}{r}1 \\
2 \\
3 \\
4 \\
5 \\
6 \\
7 \\
8 \\
9 \\
10 \\
11 \\
12 \\
13 \\
14\end{array}$ & $\begin{array}{c}\text { Compound vegetable cooking fat from RASC } \\
\text { as above } \\
\text { as above } \\
\text { as above } \\
\text { as above } \\
\text { as above } \\
\text { as above } \\
\text { Vegetable cooking fat from NAAFI } \\
\text { Vegetable cooking fat, local purchase shop } \\
\text { Beef dripping, local purchase } \\
\text { Olive oil } \\
\text { Butter from RASC } \\
\text { Beef fat from RASC } \\
\text { Ghee (Cow milk) }\end{array}$ & $\begin{array}{l}\text { Yes } \\
\text { Yes } \\
\text { Yes } \\
\text { Yes } \\
\text { Yes } \\
\text { Yes } \\
\text { Yes } \\
\text { Yes } \\
\text { Yes } \\
\text { Yes } \\
\text { No } \\
\text { No } \\
\text { No } \\
\text { Yes }\end{array}$ & $\begin{array}{l}16.2 \\
3.4 \\
0.0 \\
10.74 \\
13.9 \\
7.64 \\
67.0 \\
12.96 \\
8.93 \\
10.31 \\
1.5 \\
0.0 \\
0.036 \\
1.24\end{array}$ & $\begin{array}{l}\frac{t}{ \pm} \\
++ \\
++ \\
+++ \\
++ \\
\pm \\
= \\
=\end{array}$ \\
\hline
\end{tabular}

Note: $A$ positive Kreis test of any degree is abnormal and the normal peroxide value range is 0 - 5. In the above table ghee, animal fats and olive oil were included for comparison and it is to be noted that they show no evidence of oxidative rancidity compared to some of the vegetable fats which were grossly abnormal. Animal fats and olive oil are made up of saturated fatty acids which do not break down readily on heating. Sample 10 was an animal fat of local origin.

Table V

The environment factors of the groups of people resident in Hong Kong during 1951, 1952 and 1953, and the incidence of sprue in each group

\begin{tabular}{|c|c|c|c|c|c|c|}
\hline Group & $\begin{array}{l}\text { Hot humid } \\
\text { conditions }\end{array}$ & $\begin{array}{c}\text { Hard } \\
\text { physical } \\
\text { work }\end{array}$ & $\begin{array}{l}\text { Exposure to } \\
\text { ingestion } \\
\text { and pest- } \\
\text { borne disease }\end{array}$ & $\begin{array}{l}\text { Cooking } \\
\text { fats used }\end{array}$ & $\begin{array}{c}\text { Possible } \\
\text { oxidative } \\
\text { rancidity } \\
\text { of fats used }\end{array}$ & $\begin{array}{l}\text { Incidence } \\
\text { of sprue }\end{array}$ \\
\hline $\begin{array}{l}\text { Army } \\
\text { British }\end{array}$ & $\begin{array}{l}\text { Yes } \\
\text { Yes }\end{array}$ & $\begin{array}{l}\text { Yes } \\
\text { Yes }\end{array}$ & $\begin{array}{l}\text { Yes } \\
\text { Yes }\end{array}$ & $\begin{array}{l}\text { compound } \\
\text { vegetable } \\
\text { fats } \\
\text { Ghee }\end{array}$ & $\begin{array}{l}\text { Yes } \\
\text { No }\end{array}$ & $\begin{array}{l}\text { High in } \\
1951-1952 \\
\text { Low in } \\
1953 \\
\text { Nil }\end{array}$ \\
\hline $\begin{array}{l}\text { Civilian } \\
\text { European } \\
\text { Chinese }\end{array}$ & $\begin{array}{l}\text { Yes } \\
\text { Yes }\end{array}$ & $?$ & $\begin{array}{l}\text { Yes } \\
\text { Yes }\end{array}$ & $\begin{array}{l}\quad ? \\
\text { Ground } \\
\text { nut oil }\end{array}$ & $\begin{array}{l}\stackrel{?}{\text { No (not fried }} \\
\text { repeatedly) }\end{array}$ & $\begin{array}{l}\text { Low } \\
\text { Nil }\end{array}$ \\
\hline
\end{tabular}

author was in Hong Kong many patients were seen who presented a clinical picture similar to that of sprue but in whom the pattern was not quite typical, and in whom the diagnosis could not be proved, in that the jejunal mucosa was normal on biopsy, and patients did not have steatorrhoea. A recent study from Denver (Mann, Brown and Kern 1970) indicates that coeliac disease also has a variable clinical presentation and suggests that atypical cases may occur, noting that seven of the patients in the study described did not have steatorrhoea.

As in coeliac disease it was considered that the sprue in Hong Kong resulted from something being taken in or with the food. It had to be a substance taken regularly and it had to be in no way unusual otherwise it would be noticed by the consumer. 
Vegetable fats are made up of unsaturated fatty acids, and these fats are the most liable to break down when exposed to heat, moisture, light and aeration with the formation of ketones and peroxides which are toxic substances (Whipple 1936 and Hilditch 1947). British troops in Hong Kong were exposed to the consumption of such vegetable fats as their intake of fried meals was extremely high. Enquiry elicited that they consumed at least one and often two fried meals per day. A common story was a fried breakfast in the unit and a fried egg and chips or some similar meal in the local restaurant or NAAFI in the evening. Since the same fat was often used for repeated frying, this, with the hot humid atmosphere in Hong Kong, to which the fat was exposed between "fries", provided the ideal conditions for the development of oxidative rancidity. It may here be noted that the rancidity of the type described may not be of such a degree as to be noticed by the consumer. The question of a dietetic factor being aetiologically significant in tropical sprue has been raised by many authorities and Ayrey (1948) noted that the outbreak he described in Burma, was associated with the issue of rancid fat in the rations.

The major difficulty in considering rancid fats or the toxic products thereof, as the prime aetiological factor in tropical sprue as seen in Hong Kong, was to explain how they exerted their effect. Professor Booth (1970) in his brilliant lecture suggested that in coeliac disease the enterocyte or absorbing cell of the intestinal mucosa is damaged by the gluten resulting in impairment of its digestive and absorptive functions. It may be that the lysozome is the primary site of the intracellular damage, and the subsequent release of hydrolytic enzymes wrecks the cell. Recovery of the cell then occurs when the toxic substance is removed. Other workers have demonstrated that changes in circulating immunoglobulins $1 \mathrm{gA}$ and $1 \mathrm{gM}$ occur in patients with coeliac disease (Eidelman et al 1966, Hobbs and Hepner 1968, and Asquith, Thompson and Cooke 1969).

The whole of this hypothesis can be applied to explain the pathogenesis of tropical sprue as seen in Hong Kong, if one accepts the consumption of rancid fat as the toxic substance, acting in a manner similar to that of gluten in the case of coeliac disease. One can then understand the high incidence of the disease in the early years in Hong Kong, decreasing with improvement of hygiene and refrigeration facilities. If certain individuals are more liable to develop coeliac disease because of an abnormality of their immunoglobulins then one can accept that certain individuals will develop sprue more readily than others. On this basis one can explain the uncommon, yet nevertheless well-known, case of sprue which sometimes occurs within days of arrival in an endemic area (a patient seen by the author developed his first symptoms of sprue the day after he arrived in Hong Kong). One can even on this hypothesis offer an explanation for the equally well-known but unsolved mystery of sprue houses, so frequently described by earlier writers (Powell 1923, Manson-Bahr 1943 and Leishman 1945). These are houses in which successive colonial residents develop sprue during their term of overseas service. The explanation is that, although the resident changed, the cooking staff did not, and the same substances and methods of cooking were inflicted on successive residents. The strange geographical distribution of sprue also lends itself to a similar explanation. In hot countries like Africa where sprue does not occur, the cooking fats used are palm oil and olive oil, which are made up of saturated fatty acids, and thus less liable to develop rancidity on exposure to heat.

The epidemiology of the outbreak witnessed by the author has many facets difficult 
to explain on any other basis than that suggested. The absence of examples of the disease amongst Gurkha soldiers, Chinese residents and the extremely low incidence amongst the European residents was considered strange. Even more intriguing was the fact that most of the patients were British soldiers and as stated, of these there were some 16,000 men in the area. The Royal Air Force had only a small force stationed in detachments both in Kowloon City and on the Island of Hong Kong, and amongst them only the occasional patient was seen. One would have expected to find at least some sufferers from the disease amongst the Gurkha soldiers, when one realises that during each of the author's two tours there were some 3,000 of them in the colony. In the case of the Royal Navy, although again as stated the numbers based on land (H.M.S. Thamar) were small (539 in 1952 and 530 in 1953), nearly 10,000 naval servicemen were based on Hong Kong, and although they were frequently ashore for social purposes most of their meals were taken on board ship. They contracted the same illnesses as other service personnel with the exception of tropical sprue.

One hundred years ago Van Der Burg (1880) was perhaps nearer the truth than he realised, when he sought to explain the apparent immunity of the native population to sprue, on the grounds of their simple diet which "consisted in the main of dried fish and vegetables boiled in water".

\section{Conclusions}

That gluten is the causal factor in coeliac disease has been conclusively demonstrated by many workers, who have observed a relapse in the disease when gluten was re-introduced into the diet. A similar test of rancid fats being the cause of tropical sprue could not be applied in Hong Kong, since this would have meant feeding potentially toxic substances to soldiers on active service. Nevertheless, it is considered that the nature of the circumstantial evidence presented is almost the equivalent of such a test. It is at least sufficient to warrant serious consideration of the hypothesis submitted.

\section{REFERENCES}

Asquith, P., Thompson, R. A. and Cooke, W. T. (1969). Lancet, ii, 129.

AYREY, F. (1948). Trans, roy. Soc. trop. Med. Hyg. 41, 377.

Booth, C. C. (1970). Brit. med. J. iii, 725 and iv, 14.

Crosby, W. M. and Kugler, H. W. (1957). Amer. J. dig. Dis. 2, 236.

DickE, W. K. (1950). Coeliakie. Een onderzock naar de nadelige invloed van sonnige graansoorten op de lijder aan coeliacke. Thesis. University of Utrecht.

Eidelman, S., Davis, S. D., Lagunoff, D., and Rubin, C. E. (1966). J. clin. Invest. $45,1003$.

ENGLAND, N. W. J. and O'BRIEN, W. (1966). Gut 7, 128.

FaIRley, N. H. (1936). Lancet i, 911 .

Hilditch, T. P. (1949). The Chemical Constitution of Natural Fats. 2nd ed. Chapman \& Hall. London. Pp. 238, 274, 281 and 356.

Hobis, J. R. and HePNER, G. W. (1968). Lancet i, 217.

LEISHMAN, A. D. (1945). Lancet ii, 813.

MANN, J. G., Brown, W. R. and KeRN, F. (1970). Amer. J. Med. 48, 357.

Manson, P. (1880). China. Imp. Maritime Customs Med. Report to Shanghai 19, 33.

Manson-Bahr, P. (1943). The Dysenteric Disorders. 2nd ed. Cassell. London. P.337.

Powell, A. (1922). Trans. roy. Soc. trop. Med. Hyg. 16, 125.

ROSENTHAL, F. D. (1952). M.D. Thesis. University of London.

Rubin, C. E., Eidelman, S. and Weinstein, W. M. (1970). Gastroenterology 58, 409.

VAN Der Burg, C. L. (1883). Indishe Spruw (Apthae tropical) Rene Monographie. Batavia. Ernst \& Co. Translation in China. Imp. Customs Med. Report to Shanghai (1883-1884) 27, 55.

WebB, J. F. (1956). M.D. Thesis. Dunelm.

WeBb, J. F. and RePloh, H. D. (1969). Med. Welt (Stutt.) 516, Heft 20.

WEBB, J. F. and SiMPSON, B. (1966). Brit. med. J. ii, 1162.

Whipple, D. V. (1936). J. Pediat. 8, 734. 